\title{
Perancangan Model Return Saham Pada Perusahaan Otomotif Yang Go Public
}

\author{
Widy Setyawan ${ }^{1}$, Bramantiyo Eko Putro ${ }^{2}$, Marwan Irawan ${ }^{3}$, \\ ${ }^{1,2}$ Teknik Industri Universitas Suryakancana \\ Jl Pasir Gede Raya, Cianjur \\ ${ }^{1}$ widyft@ unsur.ac.i, ${ }^{2}$ bramantiyo@unsur.ac.id, ${ }^{3}$ marwan5irawan@gmail.com
}

Dikirimkan: 10, 2019. Diterima: 10, 2019. Dipublikasikan: 12. 2019

\begin{abstract}
The development of a good automotive industry attracts investors to invest in this industry. The current investment grows into one of the lifestyles of modern society. Individuals or groups who have excess resources will do this activity. The purpose of the investment is to earn a profit or gain additional wealth in the future. There are various forms of investment that are on real assets, financial assets, or securities (stocks, bonds, deposits, and others). Automotive companies that go public serve as subjects in this study. Because the automotive company is a rapidly growing industry. In addition, the automotive industry stocks are among the most actively traded stocks, so the stock price moves quite actively. Based on these thoughts, the authors conducted a study on the design of the model of stock returns on automotive companies that go public. The design of research model refers to the basic model of stock return. Model design on the influence of return on investment, economic value added and stock liquidity by trading volume activity method to stock return. Research data obtained by way of documentation from data of automotive companies listed in Indonesia stock exchange in the year 2013-2016. The data obtained are used to test the model empirically by using multiple linear regression method with time series problem. From the test results, it is known that roi, eva and tva effect simultaneously on stock return and for the model of each variable is explained from the results of the hypothesis that roi is accepted which means partially positive effect on stock return, while for eva and tva is rejected which means no effect on stock returns.
\end{abstract}

Keywords : Return On Inverstment, Economic Value Added, Trading Volume Activity, Stock Return

\begin{abstract}
Abstrak - Perkembangan industri otomotif yang baik menarik para investor untuk melakukan investasi pada industri ini. Investasi saat ini tumbuh menjadi salah satu gaya hidup masyarakat modern. Individu ataupun kelompok yang memiliki kelebihan sumber daya akan melakukan kegiatan ini. Tujuan dari investasi adalah untuk mendapatkan keuntungan atau mendapatkan tambahan kekayaan di masa yang akan datang. Ada berbagai macam bentuk dari investasi yaitu pada aktiva riil, aktiva finansial, atau sekuritas (saham, obligasi, deposito, dan lainnya). Perusahaan otomotif yang go public dijadikan sebagai subyek dalam penelitian ini. Dikarenakan perusahaan otomotif merupakan industri yang berkembang dengan pesat. Selain itu saham-saham industri otomotif termasuk ke dalam saham yang paling aktif diperdagangkan, sehingga harga sahamnya pun bergerak cukup aktif. Berasarkan pemikiran tersebut, penulis melakukan penelitian mengenai perancangan model return saham pada perusahaan otomotif yang go public. Perancangan model penelitian merujuk pada model dasar mengenai return saham. Perancangan model mengenai pengaruh return on investment, economic value added dan likuiditas saham dengan metoda trading volume activity terhadap return saham. Data penelitian diperoleh dengan cara dokumentasi dari data perusahaan otomotif yang terdaftar di bursa efek indonesia pada tahun 2013-2016. Data yang diperoleh digunakan untuk menguji model secara empiris dengan menggunakan metode regresi linier berganda dengan permasalahan time series. Dari hasil pengujian, diketahui bahwa roi, eva dan tva berpengaruh secara simultan terhadap return saham dan untuk model dari masingmasing variabel dijelaskan dari hasil hipotesis yang menunjukan bahwa roi diterima yang berarti berpengaruh positif secara parsial terhadap return saham, sedangkan untuk eva dan tva ditolak yang berarti tidak berpengaruh terhadap return saham.
\end{abstract}

Kata kunci : Return On Inverstment, Economic Value Added, Trading Volume Activity, Return Saham 


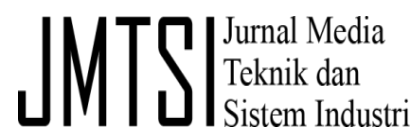

I. PENDAHULUAN

\section{Latar Belakang}

Industri otomotif merupakan industri merancang, mengembangkan, memproduksi, memasarkan, dan menjual kendaraan bermotor dunia (Yuniardi, 2015). Industri otomotif indonesia telah menjadi sebuah pilar penting dalam sektor manufaktur negara ini karena banyak perusahaan mobil yang terkenal di dunia membuka kembali pabrik-pabrik manufaktur mobil atau meningkatkan kapasitas produksinya di Indonesia. Indonesia memiliki industri otomotif terbesar kedua di Asia Tenggara, kapasitas total produksi mobil yang di rakit di Indonesia berada pada kirakira dua juta unit per tahun. Per 2017 kapasitas total produksi terpasang mobil di Indonesia adalah 2.2 juta unit per tahun. Namun, pemanfaatan kapasitas tersebut diperkirakan turun $55 \%$ pada tahun 2017 karena perluasan produksi dalam negeri tidak sejalan dengan pertumbuhan permintaan domestik dan asing untuk mobil buatan Indonesia.

Industri otomotif menjadi salah satu industri yang diunggulkan di Indonesia. Perkembangan pesat industri ini menjadi salah satu penyebab industri ini menjadi salah satu yang diunggulkan. Sejak tahun 2010 sampai tahun 2012 kapasitas produksi industri otomotif dalam negeri meningkat dari 702.508 unit menjadi 1.065 .557 unit atau sekitar mencapai $52 \%$. Data penjualan kendaraan roda empat juga meningkat dari 764.710 menjadi 1.116230 atau sebesat $46 \%$ dalam kurun waktu 3 tahun dan penjualan kendaraan otomotif di Indonesia meningkat sangat cepat [1].

Perkembangan industri otomotif yang baik menarik para investor untuk melakukan investasi pada industri ini. Investasi saat ini tumbuh menjadi salah satu gaya hidup masyarakat modern. Baik individu ataupun kelompok yang memiliki kelebihan sumber daya akan melakukan kegiatan ini. Investasi berarti menunda konsumsi sekarang untuk dimasukkan ke aktiva produktif selama periode waktu tertentu [2]. Tujuan dari investasi adalah untuk mendapatkan keuntungan atau mendapatkan tambahan kekayaan di masa yang akan datang. Ada berbagai macam bentuk dari investasi. Jika suatu kelompok atau individu ingin melakukan investasi, maka investasi dapat dilakukan pada aktiva riil, aktiva finansial, atau sekuritas (saham, obligasi, deposito,dan lainnya).

Perusahaan otomotif yang go public dijadikan sebagai subyek dalam penelitian ini. Hal tersebut dikarenakan perusahaan otomotif merupakan industri yang berkembang dengan pesat. Selain itu saham-saham industri otomotif termasuk ke dalam saham yang paling aktif diperdagangkan, sehingga harga sahamnya pun bergerak cukup aktif. Oleh karena itu pada penelitian ini berusaha membuat e-issn: 2581-0561

p-issn: 2581-0529 model prediksi return saham berdasarkan nilai ROI, EVA, dan TVA pada industri otomotif.

\section{Perumusan Masalah}

Perumusan masalah yang ada dalam penelitian ini adalah :

1. Bagaimana pengaruh return on investment, economic value added dan likuiditas saham dengan menggunakan metoda Trading Volume Activity (TVA) secara simultan terhadap return saham?

2. Bagaimana model yang dapat menjelaskan hubungan ROI, EVA dan likuiditas saham dengan menggunakan metoda Trading Volume Activity (TVA) terhadap return saham di industri otomotif?

\section{Tujuan Penelitian}

Tuhuan dari penelitian ini yaitu :

1. Untuk Mengetahui pengaruh return on investment, economic value added dan liquiditas saham dengan menggunakan metoda Trading Volume Activity (TVA) secara simultan terhadap return saham.

2. Untuk Mendapatkan model yang dapat menjelaskan hubungan ROI, EVA dan likuiditas saham dengan menggunakan metoda Trading Volume Activity (TVA) terhadap return saham di industri otomotif.

\section{METODOLOGI PENELITIAN}

Dalam penelitian ini menggunakan model regresi yang terdiri dari lebih dari satu variabel independen yang disebut analisis regresi berganda (multiple regression). Analisis ini bertujuan untuk memprediksi nilai variabel dependen berdasarkan satu atau lebih variabel independen [3].

Adapun persamaan regresi berganda dalam penelitian ini adalah sebagai berikut :

$$
Y=a+b 1 \quad R O I+b 2 E V A+b 3 T V A+e
$$

Keterangan:

$\mathrm{Y}=$ Return Saham

$\mathrm{a}=$ Konstanta

b1, b2, b3 = Koefisien regresi dari variabel bebas

$\mathrm{ROI}=$ Return On Investment

$\mathrm{EVA}=$ Economic Value Added

TVA = Trading Volume Activity

e = Faktor pengganggu dari luar model ( Error )

Pengumpulan data dalam penelitian ini dilakukan dengan metode dokumenter yaitu pengumpulan data dengan menggunakan data sekunder. Data sekunder mengacu pada informasi yang dikumpulkan oleh seseorang, dan bukan peneliti yang melakukan studi mutakhir [4]. Data tersebut berupa data laporan keuangan tahunan dari beberapa perusahaan otomotif yaitu : PT Astra Internasional Tbk, Astra Otoparts Tbk, dan Indomobil Sukses Internasional Tbk pada tahun 2013-2016 yang didapat dari Galeri Investasi 


\section{JMTS|}

Bursa Efek Indonesia dan Website Indonesian Stock Exchange (www.idx.co.id). Pengumpulan data dalam penelitian ini menggunakan data return on investment, economic value added dan tradding volume activity.

Pengolahan data dalam penelitian ini menggunakan metoda regresi berganda dengan konsep time series, dan untuk menghitungnya menggunakan software SPSS (Statistical Package For Social Sciences)

\section{Uji Asumsi Klasik}

\section{HASIL PENELITIAN}

Dalam uji asumsi klasik akan di dibahas beberapa pengujian yaitu: uji normalitas, uji multikoliniearitas, uji autokolerasi, dan uji heterokedasitas.

\section{Uji Normalitas}

1.

Untuk uji normalitas ditunjukan pada gambar

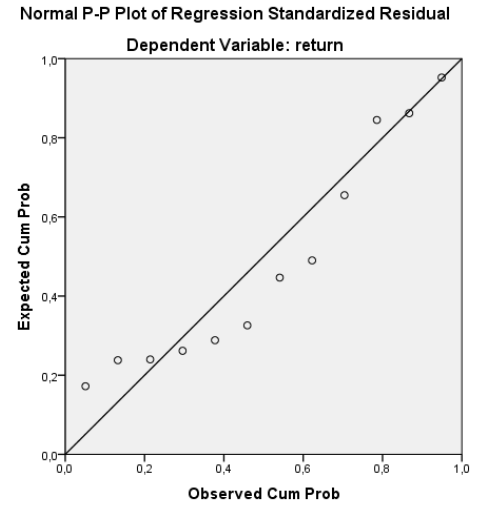

Gambar 1. Grafik Normal P-P Plot Scatterplot

Hasil uji normalitas yang disajikan menggunakan grafik Normal P- P Plot Scatterplot diketahui bahwa titik-titik yang menggambarkan ke semua variabel independen dan dependen menyebar disekitar garis diagonal dan mengikuti arah garis diagonal. Maka dapat disimpulkan model regresi memenuhi uji asumsi normalitas.

\section{Uji Multikolinearitas}

Untuk uji multikolinieritas ditunjukan pada Tabel I. Hasil uji multikolinearitas yang disajikan dengan nilai Tolerance dan VIF. Hasil uji dikatakan tidak terjadi multikolonieritas apabila nilai VIF (Variance Inflation Factor) dibawah 10 [5]. Return On Invesment (ROI) memiliki nilai tolerance 0,363 dan VIF 2,758. Economic Value Added (EVA) memiliki nilai tolerance 0,383 dan VIF 2,609. Trading Value Added (TVA) memiliki nilai tolerance 0,915 dan VIF 1,093. Semua variabel independen memiliki nilai tolerance diatas 0,1 dan nilai VIF dibawah 10. Maka dapat disimpulkan model tidak terjadi multikolinearitas.
TABEL I

UJI MULTIKOLINIERITAS

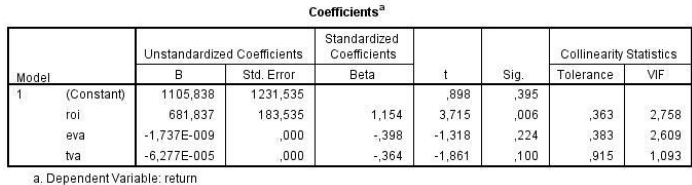

Sumber: diolah menggunakan aplikasi SPSS 20

\section{Uji Autokorelasi}

II.

Untuk uji autokorelasi ditunjukan pada Tabel

TABEL II

UJI AUTOKOLERASI

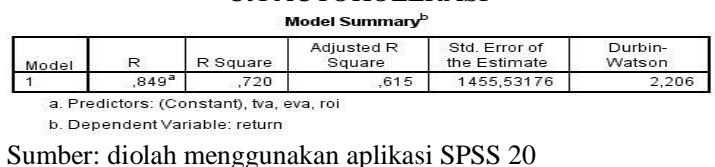

Berdasarkan hasil uji Durbin-Watson pada model menunjukkan nilai DW sebesar 2,206. Nilai DW ini lebih besar dari nilai DU sebesar 1,579 dengan $\alpha=5 \%$ dan $n=12$ yang ditunjukan pada tabel durbin watson, maka dapat disimpulkan bahwa model regresi linear berganda tidak ada autokorelasi atau bebas dari autokorelasi.

\section{Uji Heterokedastisitas}

Untuk uji heterokedastisitas ditunjukan pada Tabel III.

TABEL III

UJI HETEROKEDASTISITAS

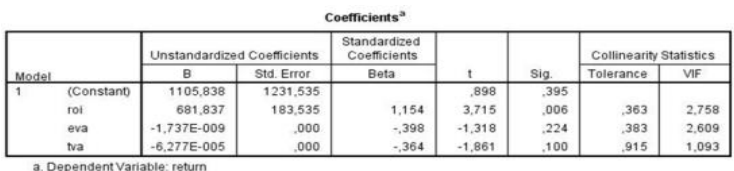

Sumber: diolah menggunakan aplikasi SPSS 20

Berdasarkan hasil uji Glejser pada model menunjukkan nilai signifikansi variabel ROI sebesar 0,006. Variabel EVA sebesar 0,224. Variabel TVA sebesar 0,100. Hasil uji Glejser tersebut menunjukkan untuk nilai EVA dan TVA signifikan diatas 0,05 . Sedangkan untuk nilai ROI tidak signifikan dikarenakan di bawah 0,05. Maka dapat disimpulkan bahwa model regresi linear berganda tidak terjadi untuk nilai EVA dan TVA, sedangkan untuk nilai ROI terjadi model regresi berganda.

\section{Time Series}

Data time series adalah nilai-nilai suatu variabel yang berurutan menurut waktu. Dalam penelitian ini data yang digunakan berupa data time series seperti yang ditunjukan pada gambar 2 . 


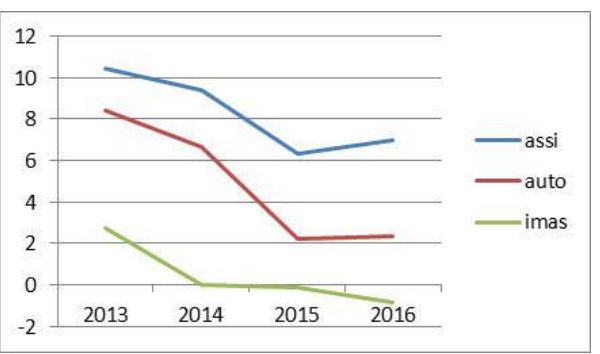

Gambar 2. Grafik Plot Data ROI

Gambar 2. menunjukan bahwa return on inverstment (ROI) merupakan data time series, karena dilihat dari hasil plot data yang dilakukan ternyata nilainya fluktuatif

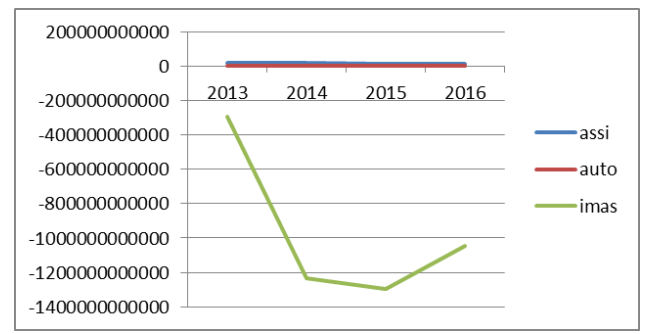

Gambar 3. Grafik Plot Data EVA

Gambar 3. menunjukan bahwa economic value added (EVA) merupakan data time series, karena dilihat dari hasil plot data yang dilakukan ternyata nilainya fluktuatif.

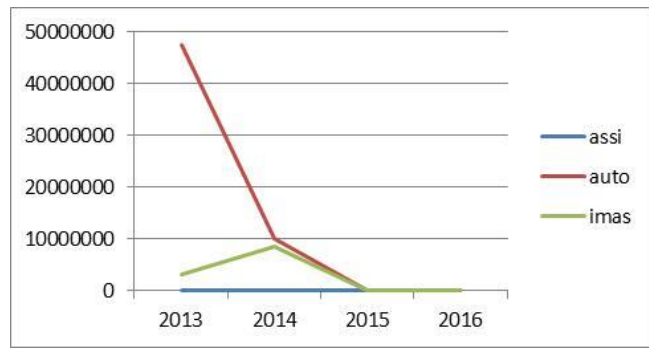

Gambar 4. Grafik Plot Data TVA

Gambar 4. menunjukan bahwa trading volume activity (TVA) merupakan data time series, karena dilihat dari hasil plot data yang dilakukan ternyata nilainya fluktuatif.

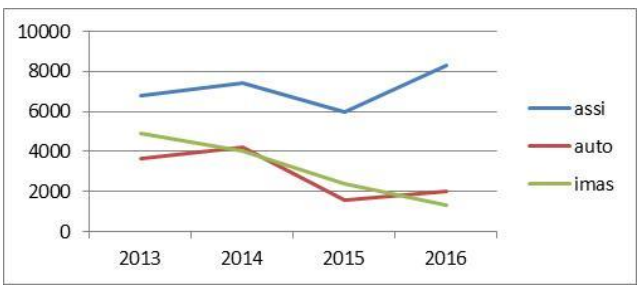

Gambar 5. Grafik Plot Data Return Saham

Gambar 5. menunjukan bahwa return saham merupakan data time series, karena dilihat dari hasil plot data yang dilakukan ternyata nilainya fluktuatif.

\section{Uji Regresi Berganda}

Pada uji regresi berganda membahas tentang konsep dasar uji regresi berganda, perumusan hipotesis, dasar pengambilan keputusan, dan pengujian hipotesis.

\section{Konsep Dasar Uji Regresi Berganda}

Pada sub bab ini akan menjelaskan beberapa konsep dasar uji regresi berganda dalam penelitian ini.

Uji regresi berganda bertujuan untuk mengetahui ada atau tidaknya pengaruh dua atau lebih variabel bebas $(\mathrm{X})$ terhadap variabel terikat (Y).

$>$ Uji t bertujuan untuk mengetahui ada atau tidaknya pengaruh parsial (sendiri) yang di berikan variabel bebas $(\mathrm{X})$ terhadap variabel terikat (Y).

$>$ Uji $\mathrm{F}$ bertujuan untuk mengetahui ada atau tidaknya pengaruh simultan (bersama-sama) yang diberikan variabel bebas $(\mathrm{X})$ terhadap variabel terikat $(\mathrm{Y})$.

$>$ Koefisien determinan berfungsi untuk mengetahui berapa persen pengaruh yang diberikan variabel $\mathrm{X}$ secara simultan terhadap variabel Y.

\section{Perumusan Hipotesis}

Pada perumusan hipotesis akan menjelaskan beberapa hipotesis yang akan dirumuskan dalam penelitian ini.

$>$ Ho : tidak berpengaruh terhadap return saham.

$>\mathrm{H} 1$ : ROI bepengaruh positif terhadap return saham.

$>$ H2 : EVA berpengaruh positif terhadap return saham.

$>$ H3 : likuiditas saham (TVA) berpengaruh positif terhadap return saham.

$>$ H4 : ROI, EVA, dan Likuiditas saham (TVA) berpengaruh positif secara simultan terhadap return saham.

$>$ Tingkat kepercayaan $95 \%, \alpha=0,05$

\section{Dasar Pengambilan Keputusan}

Pada sub bab ini menjelaskan dasar pengambilan keputusan dengan uji $\mathrm{t}$ an uji $\mathrm{F}$. a. Uji t

- Jika nilai sig $<0,05$ atau t hitung $>\mathrm{t}$ tabel maka terdapat pengaruh variabel $\mathrm{X}$ terhadap variabel Y.

- Jika nilai sig $>0,05$ atau thitung $<\mathrm{t}$ tabel maka tidak terdapat pengaruh variabel $\mathrm{X}$ terhadap variabel $\mathrm{Y}$.

$\mathrm{t}$ tabel $=t\left(\frac{\alpha}{2} ; n-k-1\right)=t(0,025 ; 8)=$ 2,306 


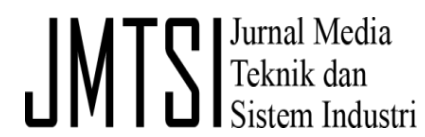

\section{b. Uji F}

- Jika nilai sig < 0,05 atau F hitung > F tabel maka terdapat pengaruh variabel $\mathrm{X}$ secara simultan terhadap variabel $\mathrm{Y}$.

- Jika nilai sig > 0,05 atau $\mathrm{F}$ hitung $<\mathrm{F}$ tabel maka tidak terdapat pengaruh variabel $\mathrm{X}$ secara simultan terhadap variabel Y.

F tabel $=F(k ; n-k)=F(3 ; 9)=3,86$

\section{Pengujian Hipotesis H1, H2 dan H3 dengan Uji} t

Pada pengujian hipotesis h1, h2 dan h3 dengan uji t menjelaskan pengujian hipotesi $\mathrm{H} 1, \mathrm{H} 2$, dan H3 dengan uji t yang ditunjukan pada Tabel IV.

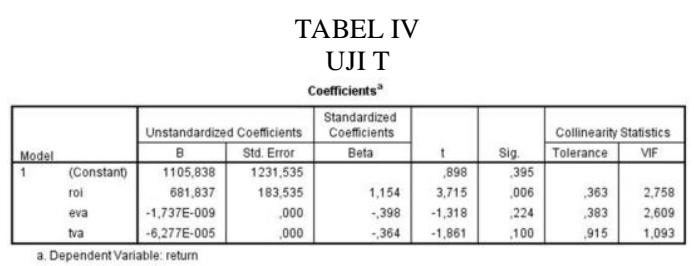

Sumber: diolah menggunakan aplikasi SPSS 20

a. Pengujian Hipotesis Pertama ROI (H1)

Diketahui nilai Sig untuk pengaruh ROI terhadap return saham adalah sebesar $0,006<$ 0,05 dan nilai t hitung 3,715 > t tabel 2,306, sehingga dapat disimpulkan bahwa $\mathrm{H} 1$ diterima yang berarti terdapat pengaruh roi terhadap return saham.

b. Pengujian Hipotesis Kedua EVA (H2)

Diketahui nilai Sig untuk pengaruh EVA terhadap return saham adalah sebesar $0,224>$ 0,05 dan nilai t hitung $-1,318<\mathrm{t}$ tabel 2,306, sehingga dapat disimpulkan bahwa $\mathrm{H} 2$ ditolak yang berarti tidak terdapat pengaruh eva terhadap return saham.

c. Pengujian Hipotesis Ketiga TVA (H3)

Diketahui nilai Sig untuk pengaruh TVA terhadap return saham adalah sebesar $0,100>$ 0,05 dan nilai t hitung $-1,861<\mathrm{t}$ tabel 2,306, sehingga dapat disimpulkan bahwa $\mathrm{H} 3$ ditolak yang berarti tidak terdapat pengaruh tva terhadap return saham.

\section{Pengujian Hipotesis H4 dengan Uji F}

Pada pengujian hipotesis h4 dengan uji $\mathrm{f}$ menjelaskan pengujian hipotesis $\mathrm{H} 4$ dengan uji $\mathrm{F}$ seperti yang ditunjukan pada Tabel V.

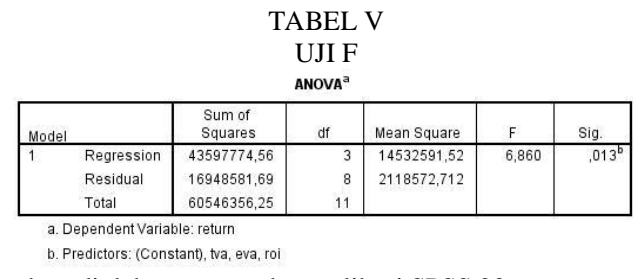

Sumber: diolah menggunakan aplikasi SPSS 20
Pengujian Hipotesis Ke empat (H4)

Berdasarkan output di atas diketahui nilai signifikansi untuk pengaruh ROI, EVA dan TVA secara simultan terhadap return saham adalah sebesar $0,013<0,05$ dan nilai $\mathrm{F}$ hitung 6,860 > F tabel 3,86 sehingga dapat disimpulkan bahwa $\mathrm{H} 4$ diterima yang berarti terdapat pengaruh antara roi, eva dan tva secara simultan terhadap return saham.

\section{PEMBAHASAN}

\section{Analisis Deskriptif}

Analisis deskriptif disini untuk membahas perusahaan. Perusahaan otomotif yang go public dijadikan sebagai subyek dalam penelitian ini. Dikarenakan perusahaan otomotif merupakan industri yang berkembang dengan pesat. Selain itu saham-saham industri otomotif termasuk ke dalam saham yang paling aktif diperdagangkan, sehingga harga sahamnya pun bergerak cukup aktif.

Pada gambar 2. Grafik Plot Data ROI dapat terlihat setiap perusahaan untuk setiap tahunnya memiliki data yang sama yaitu sama-sama mengalami penurunan untuk hasil olah data roi, dan untuk nilai terendah setiap perusahaan berada pada tahun 2016 sedangkan untuk nilai tertinggi setiap perusahaan berada pada tahun 2013. Disini menunjukan bahwa untuk setiap tahunnya setiap perusahaan memiliki keadaan yang sama dan keadaan ini mungkin disebakan juga karena ekonomi Indonesia yang mengalami penurunan setiap tahunnya, dan perusahaan Astra Internasional tbk terlihat lebih tinggi nilai roi nya dibaningkan perusahaan Astra Otoparts tbk dan Indomobil Sukses Internasional tbk.

Pada gambar 3. Grafik Plot Data EVA dapat terlihat bahwa setiap perusahaan memiliki nilai yang jauh berebeda tapi untuk setiap tahunnya setiap perusahaan hampir sama keadaanya yaitu setiap tahunnya memiliki nilai yang cenderung menurun. Dan untuk data tva masih sama untuk nilai tertinggi ada pada perusahaan Astra Internasional tbk sedangkan nilai terendah ada pada perusahaan Indomobil Sukses Internasional tbk, meskipun dari tahun 2013 sampai 2014 perusahaan Indomobil Sukses Internasional tbk mengalami peningkatan yang pesat tapi untuk tahun selanjutnya mengalami penurunan dan penurunnya melebihi perusahaan Astra Internasional tbk dan Astra Otoparts tbk.

Pada gambar 4. Grafik Plot Data TVA menunjukan bahwa nilai tva sama seperti nilai roi dan eva, nilainya cenderung menurun dari tahun 2013-2016 untuk setiap perusahaannya. Untuk nilai tva dapat dilihat disini Astra Internasional tbk yang di data roi dan eva memiliki nilai tertinggi tapi di nilai tva menjadi memiliki nilai yang terendah, dan untuk nilai tertinggi ada pada perusahaan Astra Otoparts tbk meskipun pada tahun selanjutnya 
mengalami penurunan juga.

Pada gambar 5. Grafik Plot Data Return Saham dapat dilihat pada gambar di atas setiap perusahaan mempunyai pola nilai yang berbeda. Perusahaan Indomobil Sukses Internasional tbk memiliki pola yang cenderung terus menurun dari setiap tahunnya, berbeda dengan perusahaan Astra Internasional tbk dan Astra Otoparts tbk yang memiliki pola turun naik dari setiap tahunnya.

\section{Analisis Time Series}

Analisis runtun waktu adalah suatu metode kuantitatif untuk menentukan pola data masa lalu yang telah dikumpulkan secara teratur. Analisis runtun waktu merupakan salah satu metode peramalan yang menjelaskan bahwa deretan observasi pada suatu variabel dipandang sebagai realisasi dari variabel random berdistribusi bersama. Dalam penelitian ini data yang digunakan adalah data yang berbentuk time series, seperti yang ditunjukan dalam bab sebelumnya. Dapat dilihat pada gambar dibawah ini yang menunjukan bahwa data penelitian ini berbentuk pola time series.

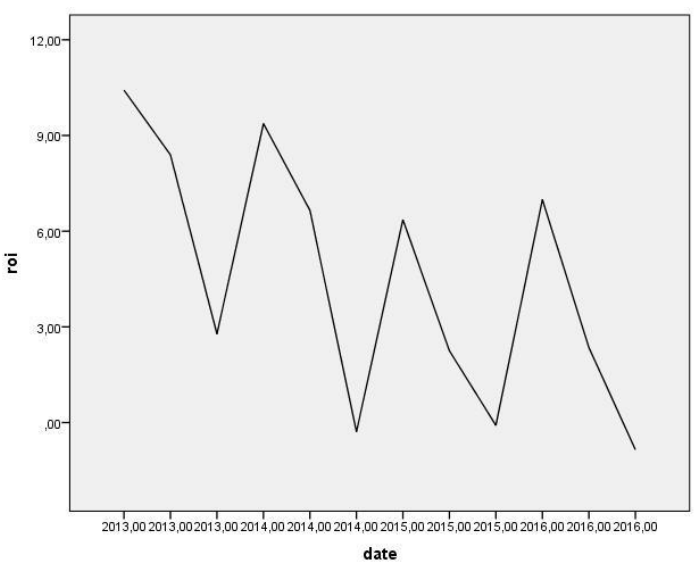

Gambar 6. Data ROI

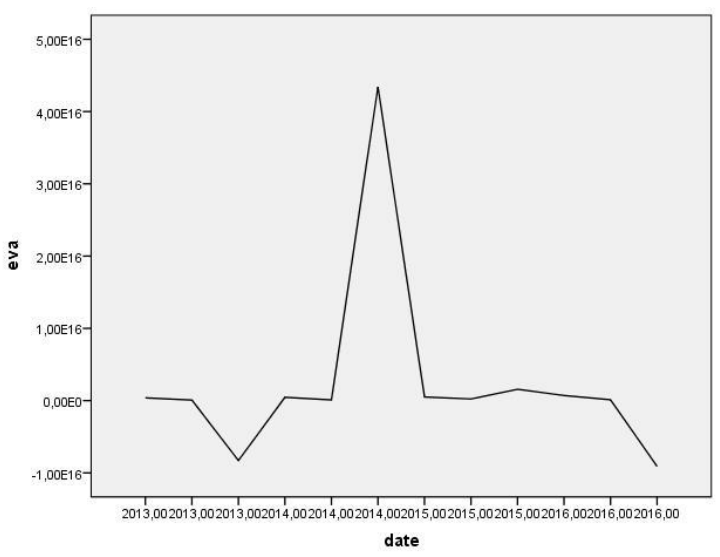

Gambar 7. Data EVA

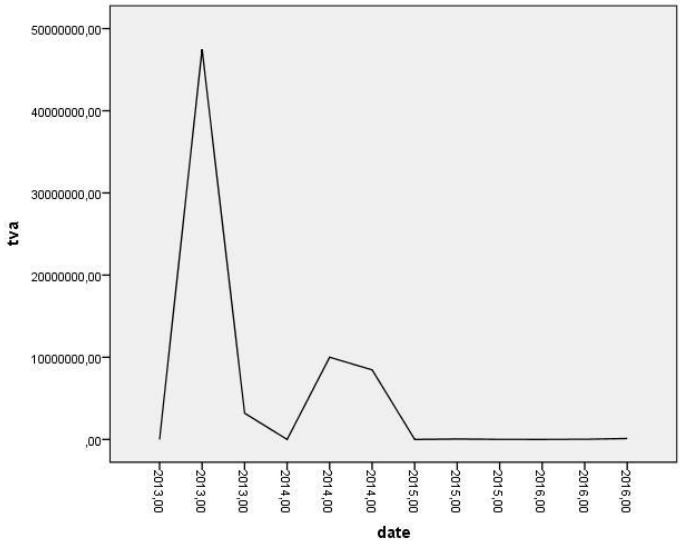

Gambar: 5.7 Data TVA

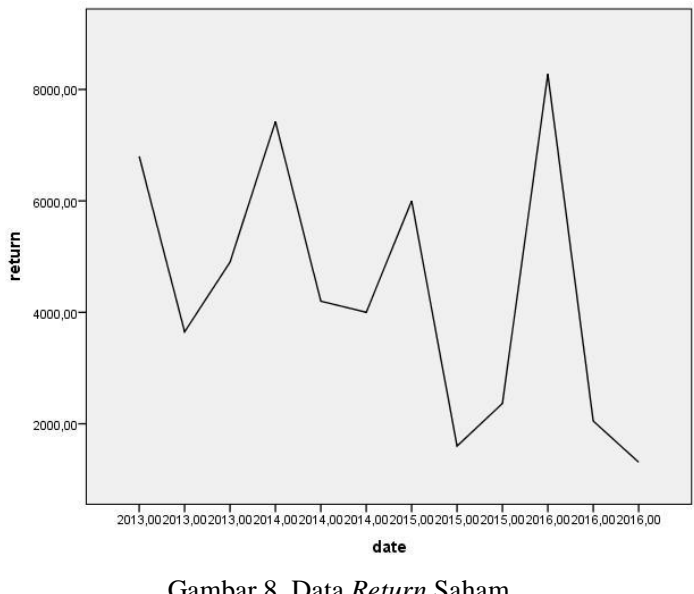

Dapat dilihat dari empat grafik di atas yang menunjukan setiap variabel dependen dan independen memiliki pola yang hampir sama yaitu cenderung naik turun dan membentuk pola yang fluktuatif. Data untuk setiap variabel membentuk pola fluktuatif juga disebabkan karena data awal yang dikumpulkan penulis memang terlihat turun naik dan juga dapat dilihat pada analisis deskriptif bahwa setiap data perusahaan saat di plot data menujukan turun naik, ditambah pada saat tahun 2013-2016 kondisi perekonomian Indonesia khususnya pada sektor ekonomi tidak stabil. Jadi dapat disimpulkan bahwa data dalam penelitian ini merupakan data time series.

\section{Analisis Regresi Berganda}

Hasil pengolahan data pada penelitian ini menunjukan bahwa variabel independen ROI, EVA, dan TVA mempengaruhi secara positif dan signifikan terhadap variabel dependen return saham. Tapi untuk variabel independen yang lebih menonjol untuk mempengaruhi variabel dependen return saham adalah variabel independen ROI. Karena variabel independen ROI mampu menerangkan $74 \%$ variansi dari variabel dependen return saham dan sisanya $26 \%$ dijelaskan oleh variabel lainnya. Seperti yang ditunjukan pada bab 4 dalam pengujian hipotesis bahwa variabel ROI 


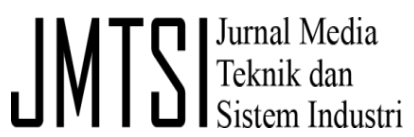

diterima yang berarti terdapat pengaruh yang signifikan terhadap return saham.

\section{Analisis Hipotesis}

Pada analisis hipotesis akan membahas tentang analisis hipotesis berisi hipotesis pertama (H1), kedua (H2), ketiga (H3), dan keempat (H4).

\section{Analisis Hipotesis Pertama ROI (HI)}

Berdasarkan Tabel IV diperoleh bahwa nilai tvalue pada hipotesis pertama adalah sebesar 0,006 $<0,05$ dan nilai t hitung 3,715 > t tabel 2,306, sehingga dapat disimpulkan bahwa $\mathrm{H} 1$ diterima yang berarti terdapat pengaruh positif secara signifikan ROI terhadap return saham. Hasil ini berbeda dengan penelitian sebelumnya yang dilakukan oleh Darmawan, Suwendra, dan Susila (2014) bahwa variabel ROI tidak diterima yang artinya tidak ada pengaruh parsial ROI terhadap return saham [6]. Untuk hasil variabel ini berbeda dengan hasil penelitian sebelumnya dikarenakan data yang dipakai berbeda, dimulai dari tahun sampai perusahaan dan juga kondisi pada tahun 2014-2016 terjadi peningkatan investor baru di pasar modal Indonesia sampai $23,47 \%$.

\section{Analisis Hipotesis Kedua EVA (H2)}

Berdasarkan Tabel IV diperoleh bahwa nilai tvalue pada hipotesis kedua adalah sebesar 0,224 > 0,05 dan nilai $\mathrm{t}$ hitung $-1,318<\mathrm{t}$ tabel 2,306, sehingga dapat disimpulkan bahwa $\mathrm{H} 2$ ditolak yang berarti tidak terdapat pengaruh EVA terhadap return saham. Hasil ini sama dengan penelitian sebelumnya yang dilakukan oleh Darmawan, Suwendra, dan Susila (2014) bahwa variabel EVA tidak diterima yang artinya tidak ada pengaruh parsial EVA terhadap return saham [6]. Untuk hasil variabel ini sama dengan penelitian sebelumnya dikarenakan sebagian sub sektor otomotif tidak membagikan dividen serta minimnya pengetahuan tentang EVA dalam pengambilan keputusan investasi.

\section{Analisis Hipotesis Ketiga TVA (H3)}

Berdasarkan Tabel IV diperoleh bahwa nilai $\mathrm{t}$-value pada hipotesis ketiga adalah sebesar 0,100 $>0,05$ dan nilai t hitung $-1,861<\mathrm{t}$ tabel 2,306, sehingga dapat disimpulkan bahwa H3 ditolak yang berarti tidak terdapat pengaruh TVA terhadap return saham. Hasil ini berbeda dengan penelitian sebelumnya yang dilakukan oleh Darmawan, Suwendra, dan Susila (2014) bahwa variabel TVA diterima yang artinya ada pengaruh parsial TVA terhadap return saham [6]. Untuk hasil variabel ini berbeda dengan penelitian sebelumnya dikarenakan kondisi pada saat itu melemahnya rupiah dan memberikan dampak negatif bagi ekonomi Indonesia dan terjadinya penurunan volume perdagangan.

\section{Analisis Hipotesis Ke Empat (H4)}

Berdasarkan Tabel V diperoleh bahwa nilai Fvalue pada hipotesis ke empat adalah sebesar 0,013 $<0,05$ dan nilai $\mathrm{F}$ hitung 6,860 > F tabel 3,86, sehingga dapat disimpulkan bahwa $\mathrm{H} 4$ diterima yang berarti terdapat pengaruh antara ROI, EVA dan TVA secara simultan terhadap return saham. Hasil ini sama dengan penelitian sebelumnya yang dilakukan oleh Darmawan, Suwendra, dan Susila (2014) bahwa variabel ROI, EVA, dan TVA diterima yang artinya ada pengaruh simultan ROI, EVA, dan TVA terhadap return saham [6].

\section{Implikasi Manajerial}

Berdasarkan analisis hipotesis maka penelitian ini dapat memberikan saran bagi pihak perusahaan untuk menjaga nilai ROI karena dalam bpenelitian ini variabel ROI mempengaruhi secara positif dan ROI juga menunjukan bahwa ROI dapat menerangkan variansi variabel sebanyak $74 \%$ terhadap variabel dependen, dan perusahaan harus mampu mempertahankan atau meningkatkan nilai ROI karena nilai ROI sangat berpengaruh terhadap return saham. Untuk mampu mempertahankan dan meningkatkan nilai ROI penulis menyarankan untuk setiap perusahaan harus bisa melakukan kebijakan pemanfaatan modal investasi dengan lebih tepat dan harus bisa memprediksi keadaan ekonomi yang sedang berlangsung serta selanjutnya. Sedangkan untuk investor baik perusahaan atau perorangan untuk memperhitungkan nilai ROI jika akan membeli saham, karena dalam penelitian ini nilai ROI sangat berpengaruh terhadap return saham.

\section{KESIMPULAN}

Berdasarkan hasil yang telah dilakukan pada studi literatur, pembentukan model, pengolahan dan analisis data maka dapat disimpulkan dari hasil penelitian yang telah dilakukan di perusahaan otomotif yang go public tentang perancangan model return saham pada perusahaan otomotif yang go public adalah sebagai berikut :

1. Pengaruh return on investment, dan economic value added dan liquiditas saham secara simultan terhadap return saham dapat dijelaskan pada penelitian ini. Nilai signifikansi untuk pengaruh ROI, EVA dan TVA secara simultan terhadap return saham adalah sebesar $0,013<0,05$ dan nilai $\mathrm{F}$ hitung $6,860>\mathrm{F}$ tabel 3,86, sehingga dapat disimpulkan bahwa $\mathrm{H} 4$ diterima yang berarti terdapat pengaruh antara ROI, EVA dan TVA secara simultan terhadap return saham. 
2. Model yang dapat menjelaskan hubungan ROI, EVA dan likuiditas saham dengan menggunakan metoda Trading Volume Activity (TVA) terhadap return saham di industri otomotif dapat dijelaskan sebagai berikut:

a. Diketahui nilai Sig untuk pengaruh ROI terhadap return saham adalah sebesar 0,006 $<0,05$ dan nilai t hitung 3,715 > t tabel 2,306, sehingga dapat disimpulkan bahwa H1 diterima yang berarti terdapat pengaruh roi terhadap return saham dengan pengaruh sebesar yang di tunjukan oleh nilai beta yaitu $\beta=681,837$.

b. Diketahui nilai Sig untuk pengaruh EVA terhadap return saham adalah sebesar 0,224 $>0,05$ dan nilai $\mathrm{t}$ hitung $-1,318<\mathrm{t}$ tabel 2,306, sehingga dapat disimpulkan bahwa $\mathrm{H} 2$ ditolak yang berarti tidak terdapat pengaruh eva terhadap return saham dengan pengaruh sebesar yang di tunjukan oleh nilai beta yaitu $\beta=-1,737 \mathrm{E}-009$.

c. Diketahui nilai Sig untuk pengaruh TVA terhadap return saham adalah sebesar 0,100 $>0,05$ dan nilai $\mathrm{t}$ hitung $-1,861<\mathrm{t}$ tabel 2,306, sehingga dapat disimpulkan bahwa $\mathrm{H} 3$ ditolak yang berarti tidak terdapat pengaruh tva terhadap return saham dengan pengaruh sebesar yang di tunjukan oleh nilai beta yaitu $\beta=-6,277 \mathrm{E}-005$.

\section{REFERENSI}

[1] Abraham Z A, 2015. etd.repository.ugm.ac.id/index.php?mod=p enelitian_detail

[2] Hartono, Jogiyanto. 2010. Teori Portofolio dan Analisis Investasi. Edisi Ketujuh. Yogyakarta: BPFE

[3] Agus, Widarjono. 2005. Ekonometri Teori dan Aplikasi, Ekonosia. Yogyakarta.

[4] Ghozali, Imam. 2005. Analisis Multivariate Dengan Program SPSS. Edisi Ketiga. Badan Penerbit Universitas Diponegoro.

[5] Hair, Joseph F. ,et al., 2006. Multivariate Data Analysis. New Jersey: Pearson Education, Inc.

[6] Darmawan A K, Suwendra W I, Susila Jana A P G, 2014. Pengaruh ROI, EVA Dan Likuiditas Saham Terhadap Return Saham Pada Sektor Keuangan Yang Go Public, Jurusan Manajemen Universitas Pendidikan Ganesha Singaraja. Indonesia. 